\title{
Poetry as a Source for the History of Early Islam: The case of (al-)'Abbās b. Mirdās
}

\author{
GERT BORG
}

\begin{abstract}
We expect poetry to be poetical, an expression of emotions, meditative and the like. It seems unusual to even consider the value of poetry as a historical source, but given the characteristics of early Arabic poetry this objective becomes less farfetched: Arab poets used their poetic compositions sometimes as the media of the time, to state publicly their points of view and their deliberations. By studying these we come across motivations, reflections of discussions and considerations of the options that these individuals had. For an era of turmoil like the beginning of Islam we can hardly come closer to the persons who witnessed it than reading and interpreting their own words.
\end{abstract}

Keywords: Ancient Arabic poetry, early Islam, genesis of religions in context.

In many medieval historical works written and compiled by Arab historians or chroniclers we find the occasional piece of poetry but these fragments are often ignored or-at besttreated as "illustrations" to the text. In the following lines I will try to demonstrate the possible contribution poetry might have to offer to our understanding of the early history of Islam.

One of the first attempts to assess the importance of poetry as a historic source was made by Omar FARRUKH in his Ph.D. thesis Das Bild des Frühislam in der arabischen Dichtung. ${ }^{1}$ Farrukh points at an interesting passage in the K. al-Aghannī:

nahā Umar b. al-Khațtāb al-nāsa an yunshidū shay'an min munāqadati l-anșāri wa-mushrikī Quraysh, wa-qāla: fì dhālika shatmu l-hayyi bi-l-mayyiti wa-tajdīdu laghāinini wa- qad hadama llāhu amra l-jāhiliyyati bi-mā jāa a min al-islāmi ${ }^{2}$

“"Umar b. al-Khațāa forbade the people to recite something (poetic ${ }^{3}$ ) that had to do with the opposition between the Anșār and the polytheists from Quraysh, arguing: that is a case of abuse by a living person towards someone who died and a revival of a grudge. Allah destroyed everything jāhili with what came from Islam."

1 FARRUKH 1937.

2 FARRUKH 1937: 2; al-Iṣfahān̄̄, K. al-Aghān̄̄, iv: 140.

3 The verb anshada allows this addition. 
The point that Farrukh wants to make is that in early Islam the reading of poetry was suppressed. The quote of 'Umar's words seems to indicate that this was done to prevent social uproar or misgivings among the believers in the new faith and their former enemies.

Whatever the purpose of this ban may have been, it shows that poetry was a social factor to be taken seriously, because it could kindle old adversities, so it must have been a threat if it alluded to existing problems. And what is more: it must have conveyed controversial opinions that were still widely held in early Islamic society.

Farrukh could not avoid discussing the authenticity problem of ancient Arabic poetry, but he sides with those who trusted the acumen and sincerity of - for instance-Ibn Hishām, maybe even more so than many of the modern Arabists tend to do. ${ }^{4}$ He quotes alQālī:

Al-Zubayr < Muḥammad b. Sallām (al-Jumaḥ̄̄) < Yaḥyā b. Sa īd al-Qaț̣ān (d. 813 A.D.):

ruwātu l-shi'ri a'qalu min ruwāti l-hadìthi li-anna ruwāta l-ḥadīthi yarwūna mașnū'an kathīran wa-ruwātu l-shi'ri sā'cata yunshidūna l-mașnū'a yantaqidūna-hū wa-yaqūlūna: hādhā mașnū'un ${ }^{5}$

"The transmitters of poetry are more sensible than the transmitters of hadith because the latter transmit much that is fabricated whereas the transmitters of poetry, when they recite something fabricated, immediately criticize it and say: this is fabricated."

Charles J. LYALL seems to be cautious about the use of poetry as a historic source but does not deny the possible usefulness: "But the poems by themselves are not, strictly speaking, history. An Arabian ode hardly ever contains a consecutive narrative of events. ... The occurrences touched upon are mentioned ... allusively..." He insists that "to utilize these poems" we have to be acquainted with the situation in which they were composed. ${ }^{6}$

In an article published in $1964 \mathrm{M}$. KHAN tries to prove the credibility and therefore the authenticity of early Islamic akhbār collections like the Sìra of Ibn Hishām, the Maghāzì of al-Wāqidī and the Tabaqāt of Ibn Sa'd, to name but a few, by evaluating and authenticating the poetry that these works contain. ${ }^{7}$

In 1968 the same author publishes an $\operatorname{article}^{8}$ that comes much closer to the subject of the present contribution. Its title is "Life of the Prophet at Mecca as reflected in contemporary poetry". In it KHAN discusses several poems by a variety of poets and tries to assess the credibility of these poems in representing the actual historicity of the Prophet's life and the circumstances of his career. In my opinion the theoretical basis of this article is a valuable contribution to Arabic and Islamic Studies. The main difference between his assessment and the present contribution is that he concentrates on the

\footnotetext{
4 FARRUKH 1937: 5.

5 Al-Qālī, (Dhayl) al-Amālē, iii: 105.

LYALL 1914: 68-9.

7 KHAN 1964: 249-87.

8 KHAN 1968: 75-91.
} 
biography of one person as mirrored in contemporary poetry whereas my objective is to present an image of an evolving personality in the context of changing social and religious circumstances as expressed in his own words.

AGHA points at the wide use that the akhbāriyyūn made of Arabic verse. ${ }^{9}$ He goes as far as to suppose that "one may even conjure up an outline ... of at least the major contours of early Arab history by solely tapping Arabic verse". But he argues that before we can work with poetry as a source two obstacles have to be overcome: we need to distinguish between contemporaneous poetry and poetry composed commemorating the event afterwards; secondly, the subject of authenticity has to be discussed for each individual poem. ${ }^{10}$

Thomas BAUER recently discussed the role that ancient Arabic poetry can play in interpreting the Koran. ${ }^{11}$ He stresses the importance of intertextuality between the Koranic text and pre-Islamic poetry and arrives at convincing new interpretations of some koranic passages. He discusses the reasons why the "somewhat bulky mass of literature" has hardly been used for interpreting the Koran: ${ }^{12}$

- the Koran should be understood in itself,

- the authenticity problem of poetry

- and the little that literary texts can contribute to understanding a religious text, a statement similar to the first one mentioned.

The authenticity problem has lost its relevance for the contemporary study of pre- and early Islamic poetry because " $[\mathrm{t}]$ he complexity of the corpus puts to rest any notions of falsity, for in order to create such an extensive literature with its own development (sometimes even its own peculiar grammar, syntax and idiom, G.B.) over a considerable time span... it would have been necessary to invent a whole history of literature."13

If we add the sheer number of verses concerned ${ }^{14}$ and try to imagine how most of these poems would have been embedded in their own "invented" historical context, the real dimensions of such a fictional undertaking become clear. An operation on this scale would hardly go unnoticed.

BAUER's argument for establishing an intertextual relationship between the Koran and early Arabic poetry is intriguing and convincing, and it promises relevant results. He hints to one aspect of this poetry that is of particular interest in this context: “... the ways in which pre- and early Islamic society has used this literature for communicative purposes". One might also say: the poets, the major poets and the lesser ones, confronted with the

9 AGHA 2011: 7.

10 AGHA 2011: 8.

11 BAUER 2010.

12 BAUER 2010: 700-3.

13 BAUER 2010: 702.

14 The Mawsü'a Shi'riyya, a CD-ROM edited by the Cultural Foundation of the U.A.E. in 2003, lists 6,820 poems $(=55,162$ verses $)$ for the jähili and mukhadram period. Some verses are of course doubly attributed, but if we add the number of poems/verses that are not presented in edited diwans and are therefore not listed in the Mawsü $c$, this number is easily outweighed. 
emergence of a new religion and the zeal of its Prophet, actually talk back to the Prophet, the members of the Islamic community and society in general, often in poetry.

Still, to identify poetry as a source with historical content and some value for historians is an unusual approach because it seems to contradict our common sense understanding of poetry as an individual expression of emotions. Therefore as a starting point I will use the following digression which will serve as a conceptual reference for the issue at hand.

\section{Digression}

In 1830 a number of circumstances led the population in present day Belgium - then part of the Kingdom of the Netherlands - to secede from the northern provinces. This political development provoked a wave of patriotic sentiment in the north and caused King William of Orange to call upon volunteers to serve in his army. This was the beginning of a military campaign called the "Tiendaagse Veldtocht" (Ten Day Campaign) which effectively continued until the next year and was a failure from the beginning: the actual partition of the country had already been decided on a diplomatic level elsewhere in Europe.

Some volunteers were recruited from universities (then called "Hoogeschool" or "Atheneum"). Most of these volunteers were-mirabile dictu-students of Theology. From the University of Groningen about 200 students joined William's forces as so called "flankeurs". Their short heroic career consisted mainly of boredom while hanging out in a number of small towns in present day (Flemish and Dutch) Brabant. The casualties were limited. Rumour has it that two of them were injured in a scuffle and one died from falling out of a tree while spying on the enemy.

Without ever confronting the enemy forces the battalion returned to Groningen in September 1831 and King William granted these students a delay for the start of their courses until October $3^{\text {rd }}$.

During the events leading up to this campaign, when the students left to fight, as well as on their return, a large number of poems were published in the media, also to be recited at various events. From a literary point of view most of these poems have to be assessed as pathetic rubbish. ${ }^{15}$ Does this poetry reflect history; can we reconstruct a "past" using these texts?

One of the poets who more or less succeeded in composing reasonably good poetry around these historic developments was B. H. LULOFS (1787-1849), professor of Dutch Language and Rhetoric at Groningen University. In a collection of his poetry edited in 1852 we find two poems concerning the Groningen student-volunteers who participated in the Ten Day Campaign, one poem composed on the occasion of their departure and one on their return.

15 VAN ZoNNEVELD 1981: 200-212. 
Both poems are composed in stanzas; the first ${ }^{16}$ has five stanzas and the second ${ }^{17}$ has fifteen. For brevity's sake we will only have a closer look at the second poem. Its stanzas can be paraphrased as follows:

Stanza 1: Welcome to you, young heroes. Rumour has told us of your courage and loyalty in the hardest of battles. Behold how young and old greet you in awe.

Stanza 2: You defied danger and bitter need, even without food, water and sleep. You never became cowards.

Stanza 3: In the heat of the hard-fought battle when the killing was going on, your courage and your loyalty to King and country did not fail.

Stanza 4: Because of you the Belgians cannot call us cowards. Former grief and misery have been forgotten; we will only die as men.

Stanza 5: Let the virgins bind garlands to the banner from which the enemy fled. Let the banner find its place next to the one that made Galen ${ }^{18}$ leave, the banner of the courageous.

Stanza 6: Young heroes! As long as you will live the fatherland will owe you, proud of those who faced death. Future generations will envy you for the occasion to fight for Holland's right.

Stanza 7: Return to quieter exercises now on the uneasy path to knowledge. First Bellona ${ }^{19}$ covered you with bloody bay leaves and now Pallas will adorn you with her olives.

Stanza 8: The garland of scholarship entwined with that of the glory of battle. May Holland's youth show how it loves the fatherland and that it wants to honour King and Country in peace and in war time.

Stanza 9: We see Europe in tears and in blood. Another people shackled in chains, its neck under a tyrant's iron foot. Principles fight principles and the truth fights lies and delusions. ${ }^{20}$

Stanza 10: Fortunate is the country in which the people do not fear the ruler and the ruler does not fear the people. Every citizen is safe by law, free from oppression. Honour for the highest and the lowest who deserves it. Order and discipline go hand in hand with rights and freedom.

Stanza 11: You, brave heroes, stay away from mutiny and false freedom. Follow the path of truth to make humanity perfect.

Stanza 12: Humanity goes forward against all odds. Perfection is its ultimate ambition.

16 "Aan de vrijwillige Flankeur-Compagnie der Studenten van Groningen en Franeker. (Bij haren uittogt en het aanbieden van een Vaandel)", in: LuLOFS (ed. SPANDAW et al.) 1851: 114-5.

17 Ibid., Flankeur-Compagnie (Bij hare terugkomst): 116-20.

18 Bishop Bernhard von Galen of Münster (1606-1678). He besieged the city of Groningen in 1672 but failed to capture it.

19 The Roman goddess of war.

20 This might be an allusion to the Russian-Polish war and the fall of Warsaw between September $6^{\text {th }}$ and $8^{\text {th }}, 1831$. 
Stanza 13: High in heaven there is God who will help his people. Who creates order from chaos and light from darkness. He will be for evermore.

Stanza 14: Welcome once more, brave heroes. You may show the banner that withstood the fire of war. Let maidens attach bay leaf crowns to it. Long live this group of courageous warriors.

Stanza 15: You, two colleagues, who exalted scholarship by war's glory, worthy the country where the Douzas ${ }^{21}$ were born. As often as we say your names, we will praise you as scholars and (military) heroes.

The choice for this particular poem is not completely arbitrary: for the purpose of this article we need some parallels to the situation in early Islam that we are going to discuss. These parallel issues are:

- the scale of events is comparable to military campaigns in early Islam;

- when using poetry to report on a military event, we have to at least divide between those who participated and those who did not. B. H. LULOFS clearly belongs to the latter;

- the situation in which the confrontation occurs should be full of tension and ambitions;

- preferably emotions should run high, or there should be much at stake, at least in the hearts and minds of those who were witnesses.

What does this poem contribute to our understanding of history; to what extent does it reveal a historical reality?

First we find a number of historical data like names and places: It mentions a geographical name (Brabant) and the misery that the volunteers went through. It emphasizes the courage of the troops while under attack (if ever they were) and their effort to save Holland's national reputation. The scene of the garlands being bound to the banner is a romantic image that introduces the female element, i.e., the maidens who handle these garlands. It also opens the possibility to refer to the earlier distress that the city of Groningen went through under Van Galen and the important role that the old banner had in those days. The stanzas six to eight emphasize the peculiar theme of combining proud scholarship with proven toughness in battle.

Secondly it refers to contemporary circumstances: The stanzas 9-12 draw a sharp contrast between the misery of the political and social situation in Europe at that time and the enlightened leadership and social equilibrium in Holland.

Thirdly it conveys something of the contemporary state of mind: "Praise be to God" is the theme of stanza 13. Stanza 14 repeats the original theme: welcome to the brave heroes. And finally the poet refers to two of his colleagues who apparently went to war alongside the "flankeurs".

This digression also allows us to construct categories of poets and texts. As for poets we could distinguish four categories:

21 Probably a reference to the family Van der Does from Leiden, famous as scholars and military men. 
1. Witness and not biased

2. Witness and biased

3. Non-witness and not biased

4. Non-witness and biased

If we would classify this poem in terms of Arabic genres it would probably be associated with madīh. By its very nature the genre madịh seems unsignificant as a source for historical research: the poet is most of the times not a witness and is certainly biased.

Although we know from other sources that the above mentioned campaign did actually take place, the value of the poem as a historical document is very limited.

1. The poet himself was a witness only to the exit and the return of the troops. He never actually saw their activity on the battlefield nor did he see the enemy.

2. The poet emphasized not only the grand historic connection (Van Galen- present situation) but also the ideology_-generally held - that Holland was attacked in spite of its good intentions and its notable position in terms of justice and democracy.

3. The reference to any historical content or situation mainly concerns the ideological motivation to go to war. The poet is obviously not aware of this "battle" belonging to minor skirmishes in the reshaping of Europe whereas the major decisions about it were made on the level of international diplomacy at that time.

It is not only the apparent clumsiness of the whole operation but also the fact that nothing actually happened that makes the poet a non-witness to a non-event.

\section{The story of 'Abbās b. Mirdās}

As a contrast to this poet I chose to discuss a number of poems by (al-)'Abbās b. Mirdās. ${ }^{22}$ This poet converted in $628 \mathrm{AD}(8 \mathrm{AH})$ and participated in the battle of Hunayn in $630 \mathrm{AD}$. He died under the caliphate of 'Uthmān (644-656); it seems safe to assume that he was born around or a little before $600 .^{23}$

His career reflects the developments during the early Islamic era: he starts as a bedouin tribal leader of the Sulaym in the Hijaz area and at the end of his life he has become a city dweller in a house either in Basra or in Damascus.

Some of the ususal sources do have these data to offer about him:

- Al-Ṭabarī in his Tārīkh ${ }^{24}$ mentions 'Abbās's discontent and his complaint to Mohammed about the partition of booty after Hunayn. Tabarī mentions the decision

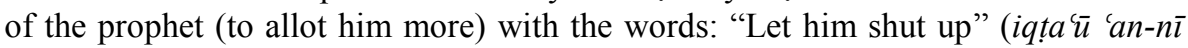
lisāna-hü).

22 Whether or not the famous poetess al-Khansāà was his mother is under debate. See al-'Abbās b. Mirdās, Dìwān: 10-11.

23 For a detailed biography of al-'Abbās b. Mirdās see "Introduction", in al-'Abbās b. Mirdās, Dīwān: 730.

24 Al-Ṭabarī, Tārīkh, ii: 174-5. 
- In his Kämil fì 'l-tārīkh, Ibn al-Athīr ${ }^{25}$ is even more concise about the story of the booty and ends with "he (the prophet) gave him until he was satisfied" (fa-acta-hu hattā rạ̣iya).

- In his Usd al-ghāba fi ma rifat al-șahāba the same author elaborates a little. He says that 'Abbās offered the army of the prophet 300 horsemen (whereas 'Abbās himself makes it a thousand as we will see). Ibn al-Athīr gives a short version of the booty

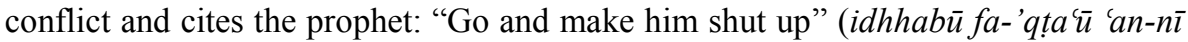
lisāna-hū); Ibn al-Athīr mentions 'Abbās's (pre-Islamic) ban on the drinking of wine $^{26}$ and the biographical note that he built a house in Damascus towards the end of his life. One hadìth is attributed to his son Kināna.

- Much more attention is devoted to 'Abbās b. Mirdās in the Sīra: ${ }^{27}$ he is mentioned as the poet of a verse praising 'Akk b. 'Adnān (I: 8); 'Amr b. Ma'dīkarib addresses 'Abbās in a verse (II: 200) and in II: 268, n. 4, we find a reference to a verse by 'Abbās; Ibn Hishām mentions a story about an idol (Ḍimār) that 'Abbās inherited from his father. The idol starts to speak about a prophet which motivates 'Abbās to convert to Islam. Elsewhere in the Sīra ${ }^{28}$ Ibn Hishām includes nine poems by 'Abbās in his account of the battle of Hunayn. All these poems except one are directly connected with this battle.

Other sources for 'Abbās are mainly from the collection of hadīth literature and are repetitive as to the information we already have.

In the following lines I would like to focus on 'Abbās, his life and his poetry, during a period which can be called turbulent: between 628 and 631 he has to choose between his loyalty towards either the tribe of Ghațafān or Hawāzin-both Qaysī tribes as well as his own tribe, Sulaym - , nonetheless he decides to convert to Islam, as a consequence he is left by his wife, and he takes part in the battle of Hunayn against the Hawāzin and is not happy with the resulting booty which brings him into conflict with the Prophet.

\section{The bet}

In his Introduction to the Dīwān of al-'Abbās b. Mirdās, ${ }^{29}$ al-JABBŪRĪ mentions a story about a wager between 'Abbās and a certain Huwayțib b. 'Abd al-'Uzzā, who was on his way with the Muslim army to Khaybar. 'Abbās places a bet that the Jews of Khaybar will prevail against the Prophet, and Huwayțib in turn puts his bet on the alternative outcome.

25 Ibn al-Athīr, Kāmil, ii: 183-4.

26 In one of his poems on the occasion of the Hunayn battle we find this verse which might shed doubt on this judgement: humū ra'su 'l-'aduwwi min 'ahli najdin fa-qatluhumū aladhdhu mina al-sharābi- al'Abbās b. Mirdās, Dīwān: 48.

27 Ibn Hishām, Sīra, i: 8, 200, 268 n. 4.

28 Ibn Hishām, Sīra, ii: 460-70.

29 al-'Abbās b. Mirdās, Dìwān: 18-9. 
Al-JABBŪRĪ interprets this as a sign of sympathy from 'Abbās for the Jewish inhabitants of Khaybar.

The source for this story - not mentioned by al-JABBŪR - might well be the Kitāb alMaghāzi by al-Wāqidī. ${ }^{30}$ The story runs a bit differently there: Huwayțib is on his way from the Treaty of Hudaybiyya with the Muslim army to Khaybar, ${ }^{31}$ convinced that the Prophet and the new religion will be victorious "over all humanity". He meets 'Abbās and the conversation heads towards a wager between the two: 'Abbās supposes that the Ghațafān (!) will win and Huwayțib of course places a bet on the Muslim army. The men of Ghațafān were hired by the inhabitants of Khaybar to help and defend them. It must have been their abilities in battle and the fact that they outnumbered the Muslims that convinced 'Abbās and a few others like Șafwān b. Umayya and Nawfal b. Mu'āwiya to place this bet.

A number of others back Huwaytib and they put in a total of 100 camels. ${ }^{32}$ The bet is on, but at that very moment there is an uproar in the middle of which Abū Sufyān b. Harb cries: khashītu wa-l-Lāti hayyiza 'Abbās b. Mirdās, "By al-Lat, this 'Abbās and his companions are getting on my nerves". Șafwān angrily replies: adrakat-ka l-MN'FYT. I suggest to read this inexplainable word as an error for munāfaqa. It would explain Șafwān's astonishment of Abū Sufyān's mistake to swear by the wrong deity: "Hypocrisy has seized you" or "Now you're exposing yourself". Abū Sufyān's reaction is to turn away in silence (askata Abū Sufyān). The details of this sub-story contribute considerably to the human character of this passage.

Because the Muslim army prevailed 'Abbās in the end lost one hundred camels with this wager.

\section{His conversion to Islam ${ }^{33}$}

For this subject we have two versions. For narrative reasons I prefer to discuss the first version elsewhere in this contribution. The second version runs like this:

\section{Version 2}

From the story of the wager we might conclude that 'Abbās did not feel as having an alliance with the Muslim community. That means that he probably had not yet converted. But very soon after this he changed his mind and went as far as taking part in the battle of Hunayn two years later. So we may assume that the time of his conversion would be somewhere between Khaybar and Hunayn. It does not necessarily mean that he took this decision at one point; he may well have taken some time to think it over. This is at least what the following texts suggest:

30 Al-Wāqid̄i, K. al-Maghāzī, ii: 701-2.

31 Also referred to as Khayābir, probably because it consisted of a number of Jewish settlements.

32 In this passage the word khumas suggests that they spread the risk over five participants.

33 The story is taken from $A g h \bar{a} n \bar{\imath}$, xiv: $302 \mathrm{ff}$. See also al-'Abbās b. Mirdās, Dīwān: $21 \mathrm{ff}$. 
He went to his camels because he wanted to go and see the prophet. He stayed with his camels overnight and in the morning trusted them to his herdsman. He ordered the herdsman to tell anyone asking about him that he went to Yathrib and not to reckon otherwise than that he wanted to go to and stay with the prophet. He mentions his reasons for doing this: ${ }^{34}$

- His paths are clear (fa-inna manāhija sabīli-hī wādịhatun).

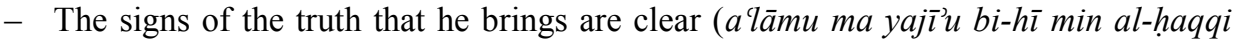
nayyiratun).

- 'Abbās is impressed by the military success of the prophet in this passage: I do not see any of the Arabs standing up against him (the prophet) against whom he (the prophet) was not rewarded with a superior victory (probably as a result of Khaybar, G.B.) (wa-lā arā ahadan min al-'Arabi yanșibu la-hū illā u'ṭiya 'alay-hi l-zafara wal-'uluwwa). ${ }^{35}$

- I have come to love him (wa-arā-nī qad ulqiyat 'alay-ya mahabbatun la-hū).

- I would give my life for his to please God (wa-anā bādhilun nafs-ī dūna nafsi-hī urīdu bi-dhālika rị̂ā ilāhi l-samāi i wa-l-arḍi).

Motivating his decision 'Abbās says the following poem: ${ }^{36}$

1. Upon my life: on the day that I zealously made Dimār accompany the Lord of Eternity $^{37}$

2. and left the messenger of God while the Aws were around him - they are his helpers and how frightening they $\operatorname{are}^{38}$

3. I was like someone who leaves the wide open plane in his (needless) want for rugged high ground to follow paths into the unknown

4. So I started to believe in God whose servant I am and I opposed the one who started to want (earthly) kingdoms

5. I turned my face towards the direction of Mecca, and I followed the blessed one between the Akhshab mountains

6. A prophet brought us after Jesus a "source" about the truth; in it is a clear statement about him as well (?)

7. A safe keeper of the Furqān the first mediator and the last one sent who answers the angels

8. The ties of Islam came together after having been broken; he brought them together until he had the rituals set up

9. I saw you, o best of all creation, in the middle of praiseworthy kinship as a ruler ${ }^{39}$

34 Aghānī, xiv: 304.

35 Aghānī, xiv: 304.

36 Aghānī, xiv: 304-5.

37 For the story about Dimār see later in this article.

38 The commentary in al-'Abbās b. Mirdās, Dīwān: 120 n. 2: istifhām lil-ta'żìm wa'l-tahwīl.

39 On mālikā both commentaries, Aghānī, xiv: 305 n.2, and al-'Abbās b. Mirdās, Dīwāan: 121 n. 2, refer to Mālik b. al-Naḍr b. Kināna b. Khuzayma b. Mudrika b. Ilyās b. Muḍar b. Nizār, the $11^{\text {th }}$ jidd of the 
10. You surpassed them in glory, generosity and lofty deeds, and to the furthest limit, where hoofs cannot reach

11. You are the pure one of Quraysh when the sayyids are together in high ranks, desiring exclusive deeds of heroes, without distraction by women ${ }^{40}$

This story seems credible: it states a sequence of events and a clear motivation for 'Abbās's choice to convert to Islam. The poem is in line with his statements mentioned earlier:

- He admits that he made a mistake by not following the prophet;

- he interprets this as a personal error (especially because he did not notice the strength of the Aws);

- he converts to Islam (apparently with the extra incentive that Islam in a way continues the preaching by Jesus);

- and he concludes his poem with madīh of the prophet.

The poem nonetheless raises a few points that are probably of interest for the study of early Islam:

- In vss. 2 and 4 'Abbās refers to God as "Allāh"; in vs. 1 however it is "rabb al'ālamīn";

- vs. 8 seems to suggest that in 'Abbās's perception "Islām" already existed; what needed to be done was "re-assemble the ties and get the rituals straight again"

\section{The follow-up}

All of a sudden the tone of the narrative becomes factual: 'Abbās offered the Prophet to go ahead of him to Medina (from) where he wanted to go to Mekka in the year of its capture. He made an appointment with the prophet at Qudayd and he (the prophet) said: "You and your people, meet me in Qudayd". When the prophet went marching to Qudayd he met 'Abbās amidst a thousand of the tribe of Sulaym. About this 'Abbās b. Mirdās says: ${ }^{41}$

1. Who will tell the people that Mohammed the prophet of God, is rightly guided wherever he goes

2. He called on his God and asked Him as the only one for help so he was fully assisted and bestowed upon

3. We travelled by night because we had an appointment with Mohammed at Qudayd, he leads us to a cause that is justified by God

prophet. Of course Mālik is a prominent name in the jāhiliyya, but it also occurs as "master": qad bittu mālika-hā wa-shāriba riyyatin qabla l-șabāhi karīmatin bi-sibāi-hā (al-Muraqqish al-Akbar, Dīwān: 84) "I stayed the night as her 'master' and drinking to my fill before the morning, a lush drinking in her captivity" (but see the commentary on sibä, 84, n. 2).

40 Following the commentary in Aghānī, iv: 305, n. 4.

41 al-'Abbās b. Mirdās, Dīwān: 141-3. 
4. They were complaining among us in the early morning until with the morning light, they made out young heroes and a forest of upright spears

5. on our horses with our coats of mail tight and footmen like a surging stream, sturdy

6. The leaders of the tribe-if you would ask them-are Sulaym and some among them trace their ancestry directly to Sulaym

7. An army of Anșār, they will not forsake him, they are obedient, not disobeying whatever he says

8. If you have chosen Khālid (b. al-Walīd) to be the commander and made him the leader, then he will certainly lead us

9. in an army that is guided by God; you, its commander, will strike with it in truth the one who has sinned

10. I have sworn a solemn oath to Mohammed and I fulfilled it: a thousand bridled horses

11. The prophet of the believers said: "Go forward (attack)!" And we were eager to do so

12. We spent the night in Nahy al-Mustadīr; we felt no fear but just awe and firmness

13. We will obey you until all humanity has converted to Islam and until we have all together become people of Yalamlam ${ }^{42}$

14. The black and white and also chestnut brown horse will get lost in the middle of it (i.e. the crowd there) and the shaykh will not feel at ease until it is marked

15. We went to attack them like sandgrouses in a row in the morning and we noticed that each one of them was oblivious about his brother

16. From the morning until we left Hunayn in the evening; by that time its waters were streaming with blood

17. If you wanted you could see from all sides a quick horse and its rider crashing down, his spear broken

18. The Hawāzin were protecting their herd against us; they always liked to see us failing and deprived

19. We hit Quraysh, their lean and their fat ones, those who do well to keep silent and those who speak (i.e. all of them) ${ }^{43}$

20. What we experience from them is something I witnessed before and I assisted in it the one who was more cautious

21. How many days did the best of us meet at $\mathrm{Mu}_{\bar{s}} \overline{\mathrm{a}}^{44}$ with tribes of Nașr and a group of Ibn Aslam

22. How much vengeance did our swords take, not to mention the spears with which we made blood flow copiously

42 Following the commentary of al-JABBŪRĪ's edition it is a mountain where the hajj passes on the way from Yemen.

43 I suggest to read: wa-an'ama hifz̧an bāla-hum fa-takallama and interpret it as a parallel to the ghayth and samin opposition. But it is a difficult passage.

44 According to the commentary in al-JABBŪRĪ's edition this is a trench of the Banū Rabī'a. 
In terms of Arabic "genres" this poem constitutes a mixture of khabar and a short madīh (of the prophet) at the beginning and halfway; towards the end it turns into fakhr. How can we classify this poem in terms of its value as a historic source?

- The poet is part and witness of the action.

- He is not impartial.

- The poem refers to persons and places, which allows us to even date it to the year 630 A.D. when the battle of Hunayn took place (vs. 16).

- A number of participants in the action are named and their role does not contradict historic data (Muhammad, Khālid b. al-Walīd, Hawāzin and Quraysh)

If we assess the position and role of the individuals and groups participating in this battle the following image emerges:

- 'Abbās has become a straightforward follower of the new religion and his relationship with the prophet is one of request and deliver: an army of a thousand men from the tribe of Sulaym in full armour.

- Because the reinforcement army of Sulaym arrived in the dark, some of the other Anșār began to complain, but they were satisfied when they saw the number of troops in daylight.

- For 'Abbās God is to a certain extent a participant: he guides the army that is led by Mohammed, while Khālid b. al-Walīe acts as a military commander.

- The Anșār were well motivated for their ultimate goal (Islamizing the world) and courageous because they believed in their cause; they just felt awe before the battle, no fear.

- The battle plan is structured: fighters took position in a row.

- A certain amount of rancour motivates at least Sulaym: the Hawāzin had apparently not been the nicest of neighbours.

- And 'Abbās also has a grudge against Quraysh, so he willingly assists one of the Quraysh, i.e. Mohammed, whom he expects to treat Sulaym better.

- The battle of Hunayn was a bloody affair.

Some elements are missing:

- 'Abbās is proud of his achievement to get 1000 men and horses together, proud to be part of the Anșār, but he leaves the bloody result of the battle uncommented. He might well have expressed pride over the result, but he does not do so.

- He presents his motivation to join the Anșār and to rally his tribe to do the same as an overnight decision. In his autobiographical notes in prose ${ }^{45}$ though, he mentions his past as a polytheist and to a certain extent tries to convey the image of his struggle to become a monotheist. Therefore we can safely assume that his conversion from polytheism to monotheism (Islam) must have been "cooking" for a while.

45 The conversion stories 1 and 2 elsewhere in this article. 
- He mentions no other options for his future; we might therefore conclude that he is glad to have joined the early Islamic community.

\section{The separation}

Apparently 'Abbās's decision to join the Muslim forces in battle was a bridge too far for his wife. Habība or Șafiyya bt. al-Ḍaḥhāk b. Sufyān al-Sulamī decides to leave him, she breaks up her tent and moves back to her family. This is what she has to say about her decision: ${ }^{46}$

1. Did it not reach 'Abbās b. Mirdās that I saw that the people are destined for disasters?

2. Every hero of the Anșār has joined them, every hero of his own tribe, defending it in adversity

3. (when), together with everyone who drops the sword fiercely, the heads of lean, intelligent horses lead him (the hero)/it (the tribe) to death

4. [By my life if you follow the din of Muhammed and leave the faithful ones and the benefactors] ${ }^{47}$

5. Then you have proudly changed this spirit for lowness on the day when the sharp blades of the swords hit against each other

6. People who are in front during the battle, intelligent people among us and people of gifts (= generous)

7. Their swords are power over the humble one and their horses are arrows for the enemy in difficult circumstances

Vss. 4 and 5 have also been translated by GOLDZIHER. ${ }^{48}$ These verses are critical, not only in the context of this poem but also with regard to the general subject of this contribution, because they contain Șafiyya's (or Habība's) motivation for her decision.

la-'amr-i la-in tāba ta dīna Muhammadin wa-faraqta ikhwāna l-șafā wa-l-șanāìi $i$ la-... tilka l-nafs... dhillan bi-izzatin ghadāta khtilāfi l-murhafāti l-qawātici $i$

GOLDZIHER's translation of line 5 is:

This soul has exchanged lowness for pride on the day when the sharp blades of the swords hit against each other

This translation poses two problems, one technical and one concerning content:

- He chose the wrong subject for the verb BDLT with which line 5 starts: the metre (tawill) does not allow to read baddalat, but it should be baddalta/i/u, which means

46 Aghānī, xiv: 306-7.

47 GOLDZIHER 1966: 18, n. 1 argues extensively why the $i k h w a \bar{n}$ al-șafă are not to be identified as the Ikhwān al-Ṣafā’.

48 Ibid. 
that al-nafs cannot be the subject of this verb. The text in al-Aghānī reads al-nafsa. It is then followed by a second object, dhillan. The phrase bi-izzatin would then have to be a third (indirect) object (Lisān al-'Arab: baddaltu l-khātima bi-l-halqati, "I replaced the signet-ring with the simple ring").

- In line with the context I prefer to assume that the verse is constructed like this phrase: fa-ulāika yubaddilu llāhu sayyi'äti-him hasanātin (Q 25:70) ("those, God will change their evil deeds into good deeds"). ${ }^{49}$

\section{'Abbās reacts to the break up of his marriage}

'Abbās takes the opportunity of the successful battle of Hunayn and the courage he showed in that battle to address the break up and to comment on Șafiyya's words of blame: ${ }^{50}$

1. What remained of the relationship with Umm Mu'ammal has in a headstrong way been cut off and she changed the intention to an unfulfilled promise

2. She had sworn by God that she would not break the ties, but she did not live up to it and did not fulfil her promise

3. A woman of the (tribe of) Khufäf, the wadi of al-'Aqīq was her resort in summer and among the Bedouins she would live in Wajra and 'Urf

4. If Umm Mu'ammal follows the unbelievers she makes my heart even more sad apart from her remoteness (from me)

5. The messenger will tell her that we did not consent and only asked our Lord for an alliance

6. and that we lived up to our promise to the leader, the prophet Muhammad of a thousand (men) whereas no other group completed that number

7. With outright heroes from Sulaym, the greatest, they obey and do not disobey one letter away from his command

8. Khufăf, Dhakwān and 'Awf, you see them like male camels, black, following the she-camel ${ }^{51}$

9. As though our reddish-white mail and helmets, like lions who meet in their dens with hanging ears ${ }^{52}$

10. In us is the strength of God's $d \bar{i} n$ without undue claims and we doubled the force of those who were already with him

11. in Mecca when we came to it as if our banner were an eagle that-after it had circled over them — wanted to grab

49 ARBERRY 1964: 368.

50 al-'Abbās b. Mirdās, Dīwān: 114-6; Ibn Hishām, Sìra, ii: 464-6. I chose to partially not use Guillaume's translation in The Life of Muhammad (GUILLAUME 1978, repr.): 580-1, because it is presented outside of its communicative cotext, the dialogue, so to say.

51 A simile to represent the adherence to their leader.

52 An image of the flaps of their helmets. So GuILLAUME 1978 (repr.): 580. 
12. those with their watchful eyes; when it hovers over their pastures you would think that there is unrest among them ${ }^{53}$

13. In the morning when we trampled down the polytheists because we did not find any compensation or regret for the cause of God's messenger

14. On a battlefield in the middle of which no one heard a whisper from us except inciting yells and the cracking of heads

15. With white swords that make the heads fly from their necks (lit.: fixing points) and with which we cut the necks of warriors

16. Many a creature did we leave behind, slain, cut into pieces and also widows, cursing their husbands in grief

17. It's God's satisfaction that we have in mind, not that of humans do we crave, because to God belongs all that is apparent and all that is hidden

His wife's accusation that 'Abbās became submissive under the new religion certainly kicked in: he does his utmost to avoid to be seen as a coward. First he states that only what was left of the relationship was cut off. Then he starts blaming her for not keeping her vow, although she belongs to the tribal elite. 'Abbās deplores her choice to opt for paganism. He seems to distance himself from his decision and points out to his wife that initially he only wanted a (profitable) alliance, but then he stresses his stable allegiance to God and to the leader, Mohammed. In vs. 13 'Abbās expresses the reason for the revenge on Quraysh: they never cared about the message of the prophet. He pictures himself as someone who takes a task on his shoulders and gets things done. Finally the desription of the bloody battle against Quraysh is straightforward fakhr.

\section{Contesting the spoils}

As mentioned earlier, a number of versions of this story circulate but the essence of the story is that 'Abbās was not satisfied with the part of the spoils that he received from the Prophet after the battle of Hunayn. He was displeased and addressed the Prophet: ${ }^{54}$

1. It was spoils that I found through my attack on the horse(s) in the plain land

2. and through my waking over my tribesmen so that they could go to sleep; when the people lay asleep, I did not

3. But my spoils and that of (my horse) al-'Ubayd became (divided) between 'Uyayna and al-Aqrac

4. I was fearless in the war but was not given anything; I should not have been deprived (?)

5. except young camels that I was given, to the number of their four legs! $!^{55}$

53 GuILlaume 1978 (repr.): ... on ist prey (riding) on horses which gazed upwards. You would think when they gallop in their bits there is a sound of jinn among them.

54 al-'Abbās b. Mirdās, Dìwān: 110-2.

55 GUILLAUME's translation (1978 repr.: 595). 
6. There was no stronghold nor confining wall better than (Ibn) Mirdās in the whole crowd

7. I was not less of a man than both of them (sc. 'Uyayna and al-Aqra'); the one that you humiliate today will not be lifted up

The end of vs. 7 sounds like a threat: if I am being humiliated, do not count on me anymore for help or military support. The prophet said: "Bring him away and cut his tongue off away from me". The bystanders appreciated the true meaning of these words, drawing 'Abbās aside and just silencing him by offering a larger part of the spoils. No wonder that this extra part was precisely 100 camels. Compare the story about the wager.

Again in terms of Arabic "genres" we are looking at fakhr in the second part of the poem. In the first three lines we read a monologue, addressed to the Prophet and the crowd of victorious but seemingly greedy warriors.

\section{Dưmūṣ and laqāḥ}

The focus of the enmity between 'Abbās and his wife is the change of 'Abbās's attitude towards power; from a tradition in which power is bestowed on the best of the tribe without hereditary succession he moves to a point where he accepts the legitimacy of power attributed to someone who does not belong to his own tribe, nor can this leader be regarded as a tribal leader in the normal sense of the word. Safiya probably felt that the young Muslim community could hardly be considered a "tribe" or Mohammed a sayyid.

One of the things we can observe is that apparently the emergence of the Prophet's message caused some strain in society, probably both on a personal and on a tribal level. The underlying causes of this strain and ensuing conflicts might lie in the transition from a tribal to - in some ways - a "modern" society. Morals and values, traditional dependencies, started to shift. This process may well have started earlier - we might even interpret the emergence of Islam partly as a result of the tension between sedentary or urban and nomadic Arabs in which the former were on the winning side.

Women felt most worried about their position: I suggested some time ago that the motivation for the poetess al-Khansā' (maybe the mother of 'Abbās b. Mirdās) to compose a large number of marāthī for her two brothers Șakhr and Mu'āwiya and to recite them at the market of 'Ukāz may well have been an attempt to glorify the jāhili concept of murü'a as opposed to moral standards as they developed within the circles of well-to-do tradesmen who populated small towns and travelled around a lot as businessmen. ${ }^{56}$

From the poem by Habība/Ṣafiyya bt. al-Ḍaḥhāk b. Sufyān al-Sulamī we might infer that what women of their status would reject was the acceptance by men of an authority outside the jăhili tradition, i.e. someone else than was chosen by the clan or tribe to be the sayyid, a rejection of any form of hereditary legitimation of power. A sayyid that would have been chosen by the clan would possess courage, loyalty and endurance and would be 
willing and able to protect the needy, in marāth $\bar{\imath}$ usually referred to as the widows and orphans (al-arāmil wa-l-yatāmā).

One would not need much more than a verse by 'Abbās like

ațañā-ka hattā aslama l-nāsu kullu-hum ${ }^{57}$

"we will obey you (Mohammed) until all mankind has converted to Islam"

to infuriate his wife who probably disapproved of any outside authority and expects her husband to be a true and independent sayyid.

The aversion of kingship among pre-Islamic Arabs is expressed in the word laqāh, for instance in the expression hayyun laqăhun, "a tribe that does not submit to kings". 'Abīd b. al-Abraș says:

abaw dīna l-mulūki fa-hum laqāḥun iḍā nudibū ilā harbin ajābu ${ }^{58}$

"they refuse to serve kings because they are laqāh (but) when they are incited to war, they will answer"

The opposite of this expression - appreciation of kingship - is the metaphor of the du'mūs, identified by ULLMANN as "larva". ${ }^{59}$ According to more recent sources the word refers to the Triops cancriformis (= tadpole shrimp) or the Triops granarius, ${ }^{60}$ both common in the Middle East. They are considered surviving fossils and live in temporary pools in desertlike areas. Because of their habitat their life cycle is short. Eggs are left in the temporary pool and can survive up to ten years of drought after which a new generation of triops simply re-appears.

This typical feature must be the reason behind the metaphor. The word $d u^{\prime} m \bar{u} s$ was used for someone who keeps popping up at the courts of kings. ${ }^{61}$ ULLMANN mentions a number of Belege but this specific use of the metaphor seems to be limited to hanif-poetry. There are two very similar instances, in both cases by haniff-poets, who seem to be proud that they or their tribesmen are regular visitors of kings:

In a poem in which he explains his behaviour as an inquisitive man Zayd b. 'Amr b. Nufayl says of himself:

du'mūṣu abwābi l-mulū- $\quad$ ki wa-jāỉbun li-l-kharqi nābu-h

"popping up at the gates of kings, and his camel crossing the desert" (G.B.) ${ }^{62}$

57 Aghānī, xiv: 306.

58 Dìwān 'Abìd b. al-Abraș, 29.

59 ULLMANN 1995: 145-60. It is difficult to identify the du'mūs. Based on elaborate work on a variety of sources Ullmann argues that the most probable meaning is 'larva'.

60 See for instance <http://ar.wikipedia.org/wiki/دعموص> and <http://commons.wikimedia.org/wiki/ Category:Triops $>$.

61 See for instance al-Zamakhsharī, Mustaqșā, I: 118: ...du 'mūss wa-huwa al-rajul al-dakhkhāl fì 'l-umūr al-zawwār lil-mulūk "... the du 'mūṣ, a meddlesome man, a frequent visitor of kings".

62 IBN HISHĀM, Sīra, I, 229. In GUILLAUME's translation, Life of Mohammad, 102: A man who persistently frequents the gates of kings / Whose camel crosses the desert. 
And Umayya b. Abī l-Șalt says in his marthiya on the victims of Badr:

dúmūsși abwābi l-mulū- $\quad$ ki wa-jāìibin li-l-kharqi fătih

"popping up at the gates of kings (G.B.), crossing the desert, victorious" 63

\section{'Abbās's conversion, version 1}

This version of the circumstances in which 'Abbās converted to Islam is not important in itself or in the parenthesis to the other story, referred to before as version 2, but within the framework of the chapter about 'Abbās in the K. al-Aghānī as such. Until now I had to deviate from the narrative order of this chapter: 'Abbās's poem with his reaction to the separation and his bragging about his heroic deeds in the battle of Hunayn is missing in Abu l-Faraj's account. It seemed logical to add it to the first separation fragment here.

Another story missing from the Aghānī is the wager between 'Abbās and Huwayțib. Because this wager took place immediately before Khaybar and obviously before 'Abbās's conversion it had to be placed before both accounts.

Version 1 of 'Abbās's conversion is a different case: it precedes version 2 in the $A g h \bar{a} n \bar{\imath}$, which in itself is peculiar because both show some common factual ground, but version 1 is of a completely different nature. It runs like this:

'Abbās inherited an idol from his father named Ḍimār. He committed himself to build a shrine (?) (bayt) around it and went to it each day and night. When the message of the Prophet appeared the deity spoke to him in verse: ${ }^{64}$

1. Tell all the tribes of Sulaym: the friend has died; long live the people of the mosque (masjid)

2. The one from Quraysh who inherited prophethood and guidance after the Son of Maryam is well guided

3. Dimār has perished; it was once worshipped before the book (came) to the prophet Mohammed ${ }^{65}$

Later on 'Abbās has an apparition of the prophet when he falls asleep on his camel, after which he decides to acknowledge the Prophet as his leader, convert to Islam and return to his home country to burn the deity Dimār.

In this story miraculous things happen - a talkative piece of wood, an apparition in a dream-but it all ends well. ${ }^{66}$ The story has a high "grandpa-tell-us-a-story" quality. The

63 Dìwān Umayya b. Abī al-Salt, 25; in Guillaume's translation (1978 repr.: 354): "Constantly at the gate of kings / Crossing the desert, victorious".

64 Aghānī, xiv: 303.

65 I chose to translate the perfect tenses as optatives.

66 Al-JABBŪRI, in his commentary, calls it a story with a lot of fiction (tazayyud, ifti ${ }^{i} \bar{l}$ ) but considers it indicative for 'Abbās's personality and background—al-'Abbās b. Mirdās, Dīwān: 21. 
poem cited in this story as the words of the speaking deity hardly qualifies as being of any historic or referential value. Indeed one might for instance wonder if there were any masājid at the time of 'Abbās' conversion. The last verse is a bit clumsy lacking a verb for "reached". It seems that this poem deserves a different approach from than the other poems.

Hilary KILPATRICK distinguishes five kinds of story-telling in the K. al-Aghānī. ${ }^{67}$ Two of the types qualify as applicable in the case of the chapter in the Aghāni about al-'Abbās b. Mirdās:

- chronological organization

- alternation of themes

The chronology of episodes is the strongest organizational principle in the akhbār about 'Abbās, but here and there we can sense a slight tendency towards the second kind of organization, defined by KILPATRICK as follows: "Such articles are reminiscent of those mediaeval paintings or icons in which the subject's portrait, his essence, as it were, is surrounded by little scenes depicting characteristic incidents from his life." In the story of 'Abbās, Abū l-Faraj seems to mingle the two organization principles. So this might be an example of the "mixed form" that KILPATRICK pre-supposes.

The 'Abbās chapter starts with the almost ubiquitous exposé of his lineage and a short hint at the "spoils" theme, probably to indicate his closeness to the Prophet. But as soon as the storyteller takes over, 'Abbās's conversion is the start of it all. It is at this point that Abu 1-Faraj may have decided to mention both versions, just to be complete. But I think we have to bear in mind that narration time is not necessarily identical with narrated time. In that sense version 1 of 'Abbās's conversion to Islam may well be a fictional representation in hindsight towards the end of his life.

\section{Conclusion}

It would be hard to argue that it is not 'Abbās b. Mirdās or his wife who are talking: their words fit their situation and the changes inside and outside their relationship. 'Abbās becomes a fervent supporter of the prophet and the new religion, although he is keen to see his personal ambitions and profit fulfilled. His wife however sees things differently, distances herself from this modernism and wishes to cling to traditional values. ${ }^{68}$

If we accept this position, if we see these poems as personal statements, they convey the image of a society in which Islam was met with enthusiasm, but it is also clear that it caused considerable stress and anxiety: traditional alliances between clans were breaking up, traditional relationships did not hold under this cultural-ideological strain, and aspirations in life were suddenly re-defined. These poems illustrate how drastic the preaching of this new religion was and the impact it had on early Islamic history.

67 KILPATRICK 1996: 242-58. For this distinction see 250-2.

68 Ironically Habība's (or Șafiyya's) conclusion would be more in line with modern behavioural patterns than those that are — rightly or wrongly—associated with Islam. 
The continuity and discontinuity of tradition and innovation that went along with this emergence of Islam characterizes "par excellence" a period of such upheaval, putting long lived values and convictions under stress.

'Abbās witnessed the turbulent years between 628 and 630 AD. He had to make choices, both superficial and principal. But considering the loss and gain of 100 camels it also seems that his "career change" is not completely void of some opportunism.

Two methodological principles are prominent in the discussion about the historical value of early Arabic poetry:

1. The poems can best be interpreted as historical sources in chronological order; sometimes this order has to be reconstructed on the basis of the content of these poems.

2. The poetic material cannot provide us with answers to every kind of questions.

Ad 1: These poems can only be studied and interpreted as interdependent texts in their chronological order. This intertextual approach has proved to be fruitful and can open new horizons in our understanding of (early) Arab culture as Thomas BAUER's Altarabische Dichtkunst ${ }^{69}$ shows: Arab poets actually knew each others' works and poets reacted to these texts, always trying to improve earlier poems. In doing this BAUER addresses a number of problematic items in early Arabic poetry at once: the creative technique, the historic links between these poets and the authenticity of the poetic material itself.

Another example of intertextual relationship in early Arabic poetry was my attempt to reconstruct the human aspects involved in the run-up to the Harb Basūs: interdependent poems that revealed the drama of recklessness, anger, shame and distress in a very complicated relational situation. ${ }^{70}$

Ad 2: It is hardly fruitful to look for factual data in poetry. Where 'Abbās claims to lead a thousand warriors to Hunayn, this number must be questioned or interpreted as mubālagha and/or fakhr. Three hundred would probably be a more appropriate estimation. A final methodological question is whether or not the findings in this poetical material can be generalized. We have to realize that—maybe apart from the $l u s ̣ \bar{u} s-$ we are discussing works of poets who belonged to or were associated with the elite of pre- Islamic society. One might argue that their feelings, considerations and conclusions were not only personal but more widely felt within their own families and tribes. But in a tribal society that was breaking up along religious lines and in which religious groups were forming, this is not necessarily true and has to be verified with other data. One could imagine that the process to do so would have three steps:

- The construction of (parts of) biographies on the basis of poetry and the small stories that go with it.

- Comparison of these data with other sources like hadīth, sīra and maghāzīliterature, the result of which can be threefold: poetry would corroborate these

69 BAUER 1992.

70 BORG 1997: 185-94. 
sources, clarify them or contradict them, in which case the result would at least be a definable problem of interpretation.

- Extrapolation of the result to a story that would at least have a reasonable claim to being historical.

And it would be interesting to see if and how the developments we can trace resulted in a shift in the role of poets as spokesmen for their tribe to spokesmen for religious and political groups. And how the role of poets changed with an elite that started as gentry, became chivalry in the era of Islamic expansion and ended as nobility at the Arab-Islamic courts.

\section{References}

\section{Primary sources}

[al-'Abbās b. Mirdās al-Sulamī]: Dīwān al-'Abbās b. Mirdās al-Sulamī / ed. Yahyā al-JABbūrī. Beirut: Mu’assasat al-Risāla, 1991.

['Abīd b. al-Abraș]: Dīwān 'Abìd b. al-Abraṣ / ed. Ḥusayn NAș̣̦ĀR. Cairo: Sharikat Maktabat waMaṭba'at Muștafāa al-Bābī al-Ḥalabī wa-Awlāduh, 1957.

Ibn al-Athīr: al-Kāmil fì 'l-tārīkh / several editors. Beirut: Dār al-Kitāb al-'Arabī, [s.d.].

Ibn Hishām: al-Sìra al-Nabawiyya / ed. M. al-SAQQĀ (et al.). Cairo: Sharikat Maktabat wa-Maṭba'at Mușțafā al-Bābī al-Ḥalabī wa-Awlāduh, 1955.

al-Ișfahānī: K. al-Aghān̄i / several editors. Cairo: (reprint of the Dār al-Kutub edition), [s.d.].

(al-) Muraqqish al-Akbar: Dīwān al-Muraqqishayn / ed. Kārīn ȘĀDIR. Beirut 1998.

al-Qālī: Dhayl al-Amālī wa 'l-Nawādir / several editors. Beirut: Dār al-J̄̄l, 1987.

al-Ṭabarī: Tārīkh al-umam wa'l-mulūk / ed. anonymous. Beirut: Dār al-Kutub, 1988.

al-Wāqidī: Kitāb al-Maghāz̄̄ / ed. Marsden JonES. London: Oxford University Press, 1966.

al-Zamakhsharī: al-Mustaqșā fì Amthāl al-'Arab / ed. anonymous. Beirut: Dār al-Kutub al-'Ilmiyya, 1987.

\section{Secondary sources}

Agha, Saleh Said. 2011. "Of Verse, Poetry, Great Poetry, and History”. In: R. BAAlBaKKi (et al., eds.), Poetry and History, American University of Beirut Press, Beirut.

ARBERRY, A.J. 1964. The Koran Interpreted. Oxford University Press, London.

BAUER, Thomas. 1992. Altarabische Dichtkunst: eine Untersuchung ihrer Struktur und Entwicklung am Beispiel der Onagerepisode. Harrassowitz, Wiesbaden.

BAUER, Thomas. 2010. "The Relevance of Early Arabic Poetry for Qur'ānic Studies Including Observations on kull and on Q 22:27, 26:225, and 52:31". In: NEUwIRTH (et al., eds.) 2010: 699-730.

Borg, Gert. 1997. Mit Poesie vertreibe ich den Kummer meines Herzens: eine Studie zur altarabischen Trauerklage der Frau. Nederlands Historisch-Archaeologisch Instituut, Istanbul. 
Cultural Foundation of the U.A.E. (ed.). 2003. al-Mawsū'a al-shi'riyya. CD-ROM. Cultural Foundation, United Arab Emirates, Abu Dhabi.

FARRUKH, Omar A. 1937. Das Bild des Frühislam in der arabischen Dichtung von der Higra bis zum Tode Umars 1-33 D.H./622-644 n.Chr. August Pries, Leipzig.

Goldziner, Ignaz. 1966. Muslim Studies / ed. S. M. Stern. George Allen \& Unwin LTD., London.

Guillaume, A. 1978 (repr.). The Life of Muhammad. Oxford University Press, Oxford.

Khan, M. 1964. "A Critical Study of the Poetry of the Prophet's time and its Authenticity as the Source of Sira". Islamic Culture, 38/1: 249-87.

KHAN, M. 1968. "Life of the Prophet at Mecca as Reflected in Contemporary Poetry." Islamic Culture, 42/2: 75-91.

Kilpatrick, Hilary. 1996. "Modernity in a Classical Arabic Adab Work: The Kitāb al-aghān $\vec{\imath}$ '. In: SMART (ed.) 1996: 242-58.

LuLOFS, B.H. 1851. Gedichten, na zijn overlijden verzameld en uitgegeven / ed. by A. H. SPANDAW (et al.). Schierbeek, Groningen.

Lyall, C.J. 1914. “Ancient Arabian Poetry as a Source of Historical Information”. Journal of the Royal Asiatic Society, 46/1: 61-73.

Neuwirth, Angelika (et al., eds.). 2010. The Qur'an in Context: Historical and Literary Investigations into the Qur'anic Milieu. August Pries, Leiden-Boston.

SMART, J. R. (ed.). 1996. , Tradition and Modernity in Arabic Language and Literature. Psychology Press, Richmond (UK).

Ullmann, Manfred. 1995. "Was bedeutet arabisch du'mūṣ?” Die Welt des Orients, 26: 145-60.

VAn ZonNeveld, Peter. 1981. "De Belgische Opstand en de Nederlandse literatuur”. De Negentiende Eeuw, 5: 200-12.

\section{Appendix: The Texts}

a) 'Abbās' conversion, see above pp. 146-147

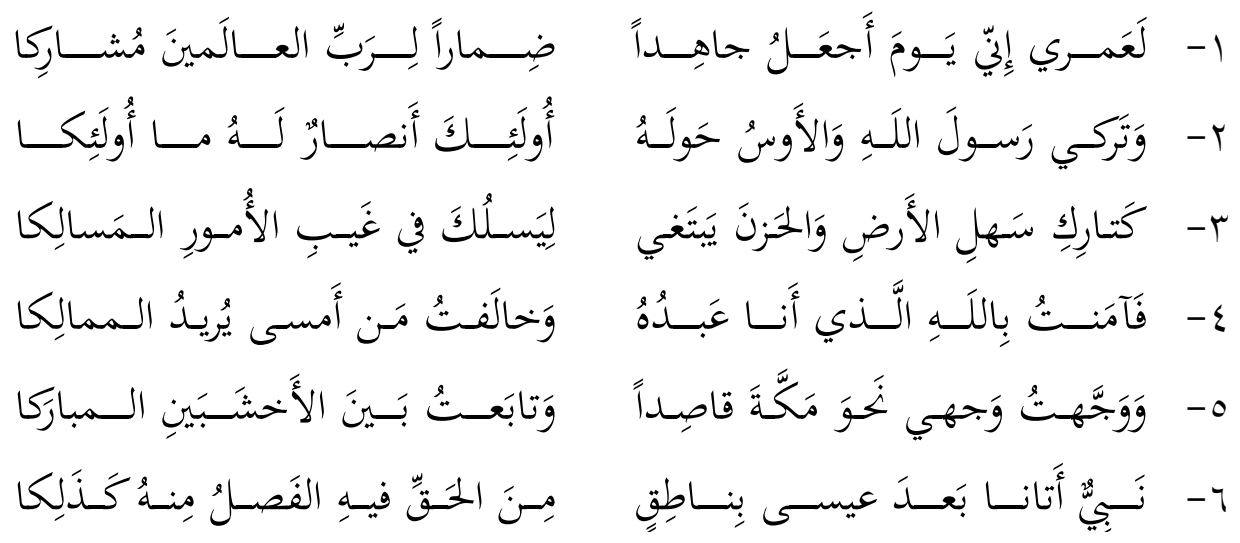




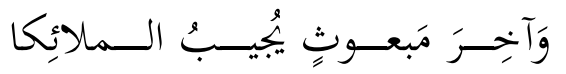

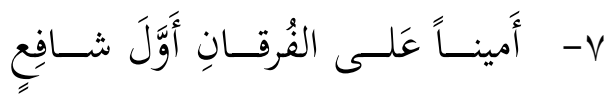

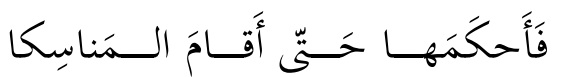

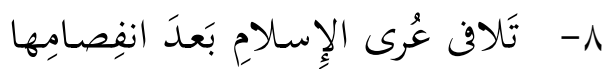
تَوَسَّطتَ في القُربى مِنَ المجدِِ مالِكَا

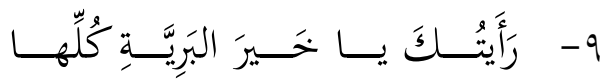

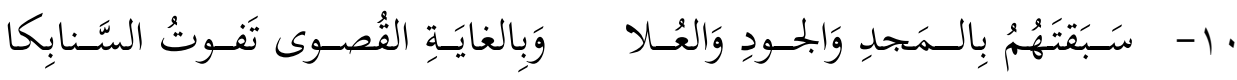

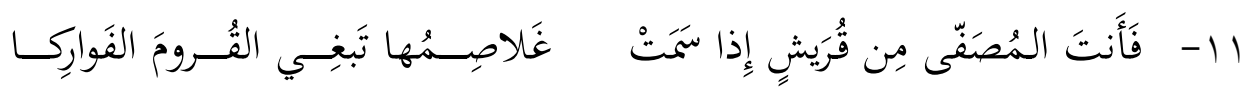

b) 'Abbās explains his conversion, see above pp. 147-148. Dīwān 'Abbās, 141-143.

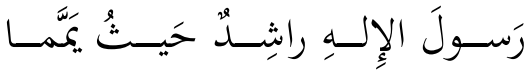

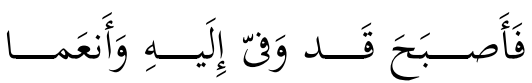

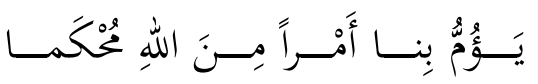

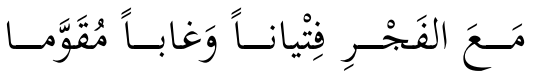

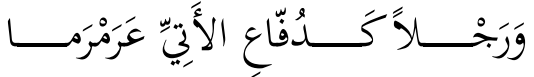

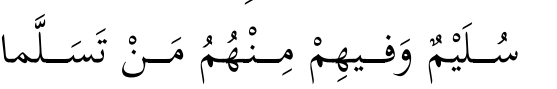

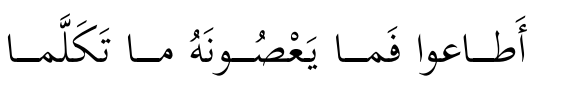

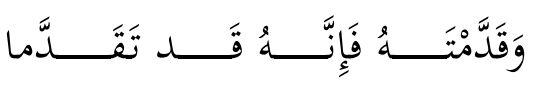

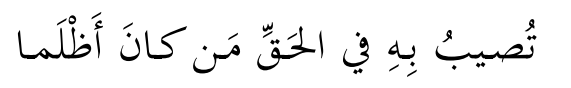

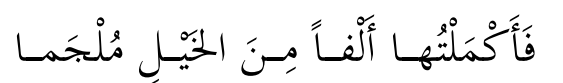

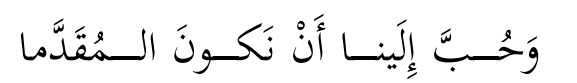

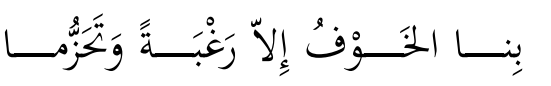

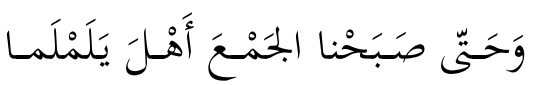

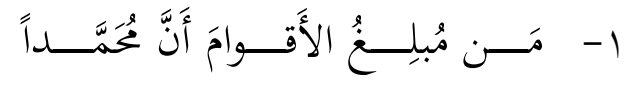

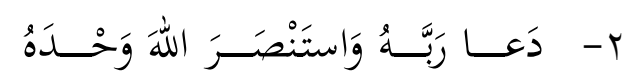

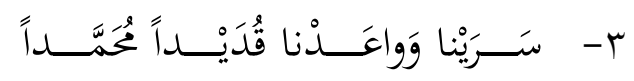

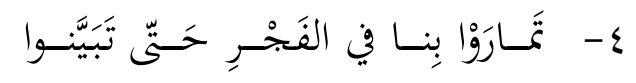

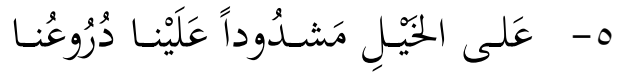

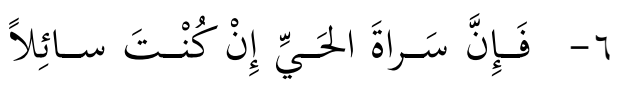

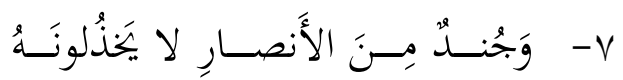

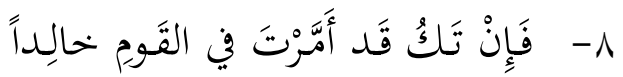

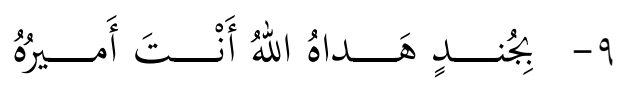
.

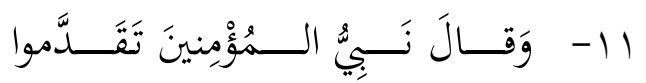

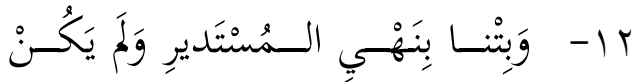
برا 


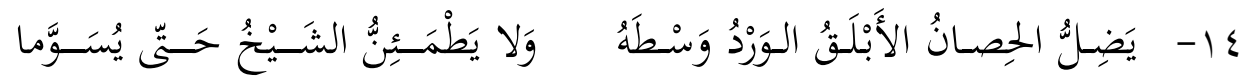

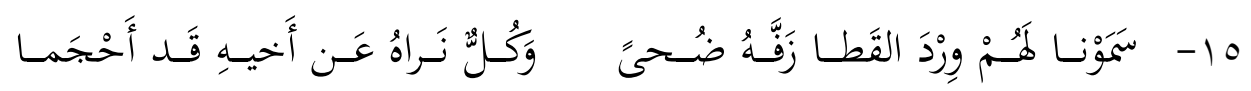

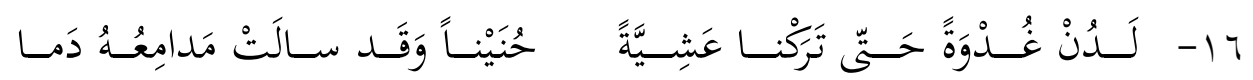

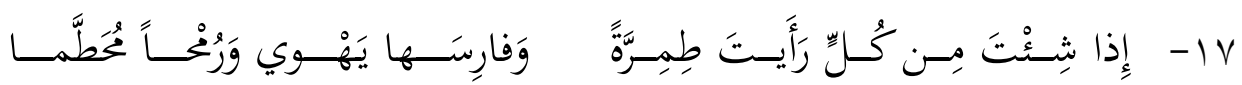

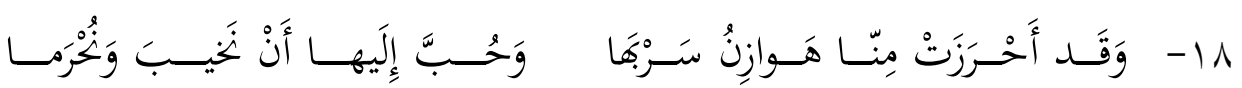

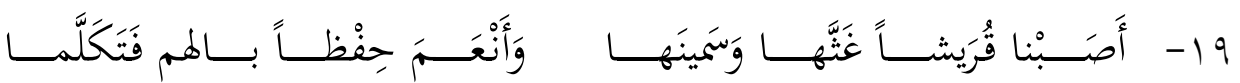

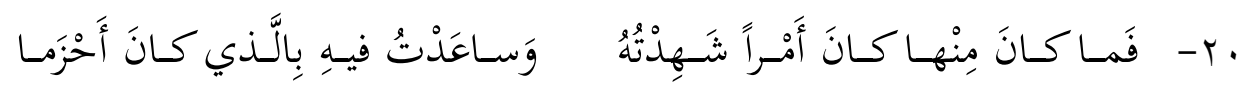

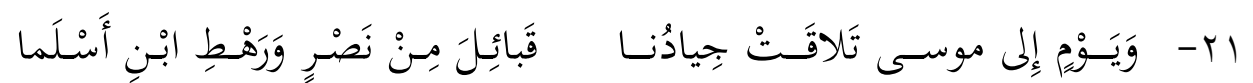

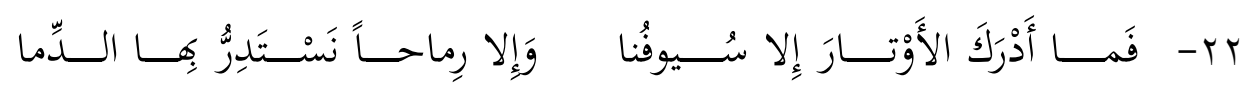

c) 'Abbās's wife reacts, see above p. 150. Aghānī, 195.

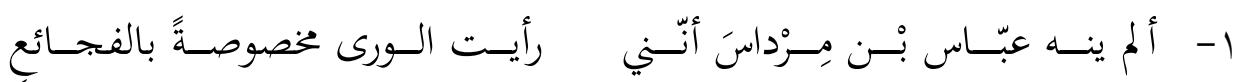

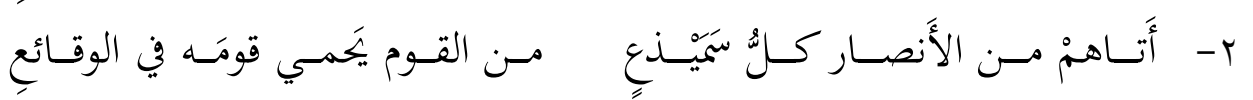

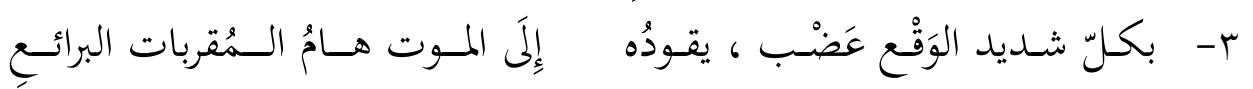

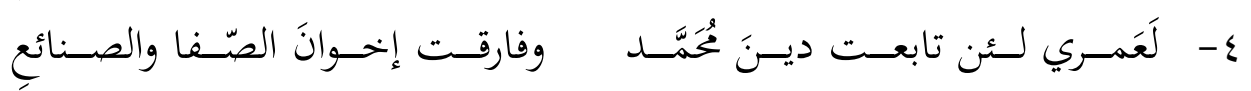

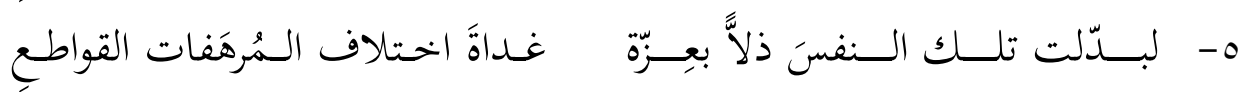

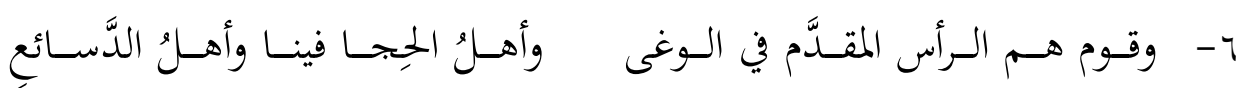

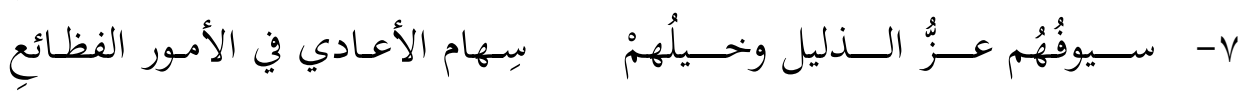


d) 'Abbās reacts to his wife's poem, see above pp. 151-152. Dīwān 'Abbās, 114-116.

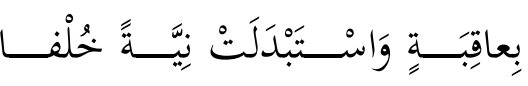

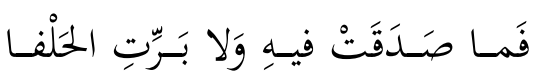

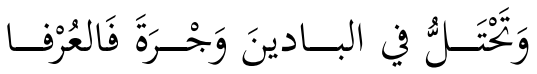

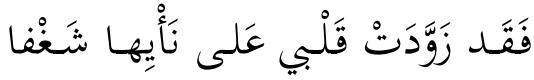

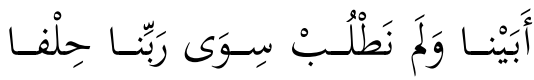

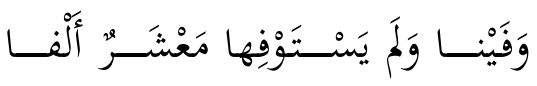

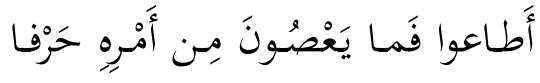

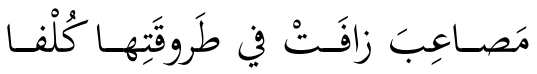

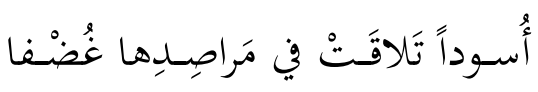

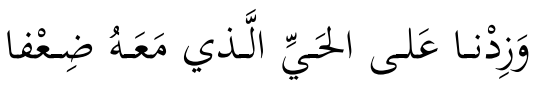

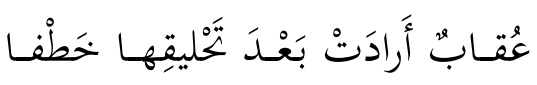

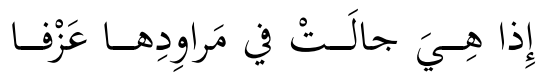

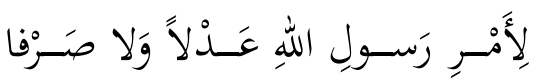

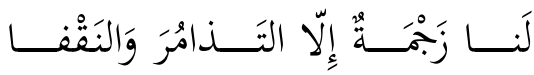

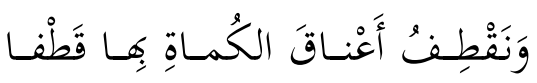

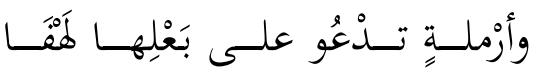

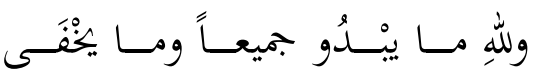

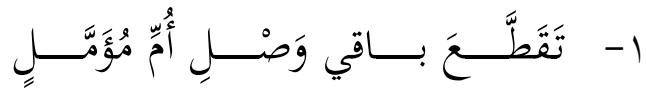

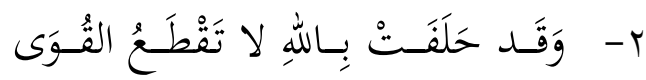

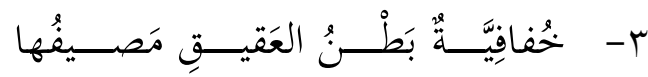

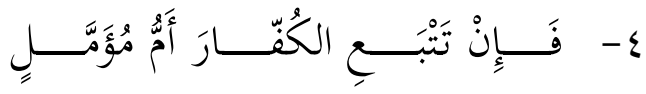

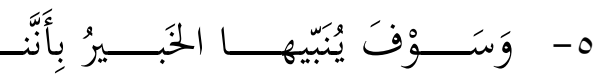

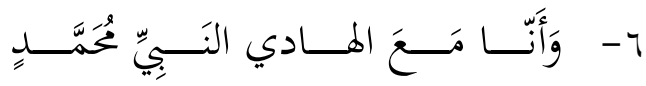

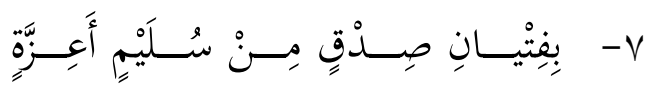

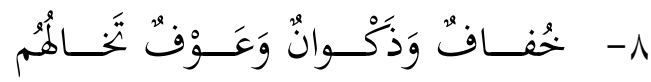

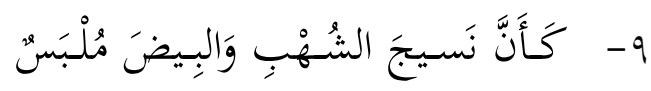

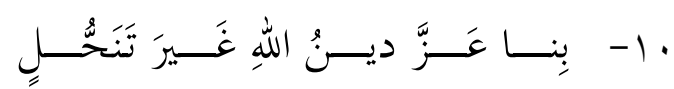

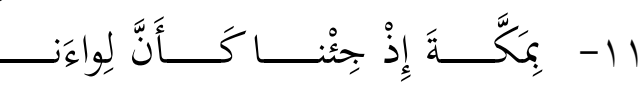

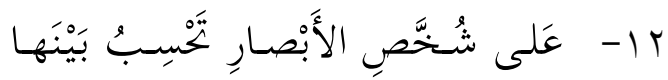

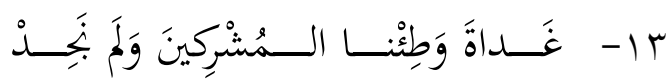

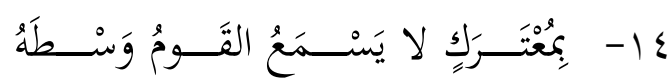

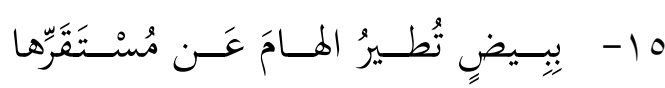

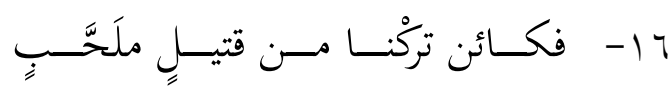

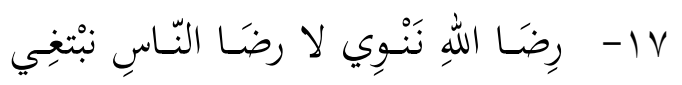


e) Contesting the spoils, see above pp. 152-153. Dīwān 'Abbās, 111-112.

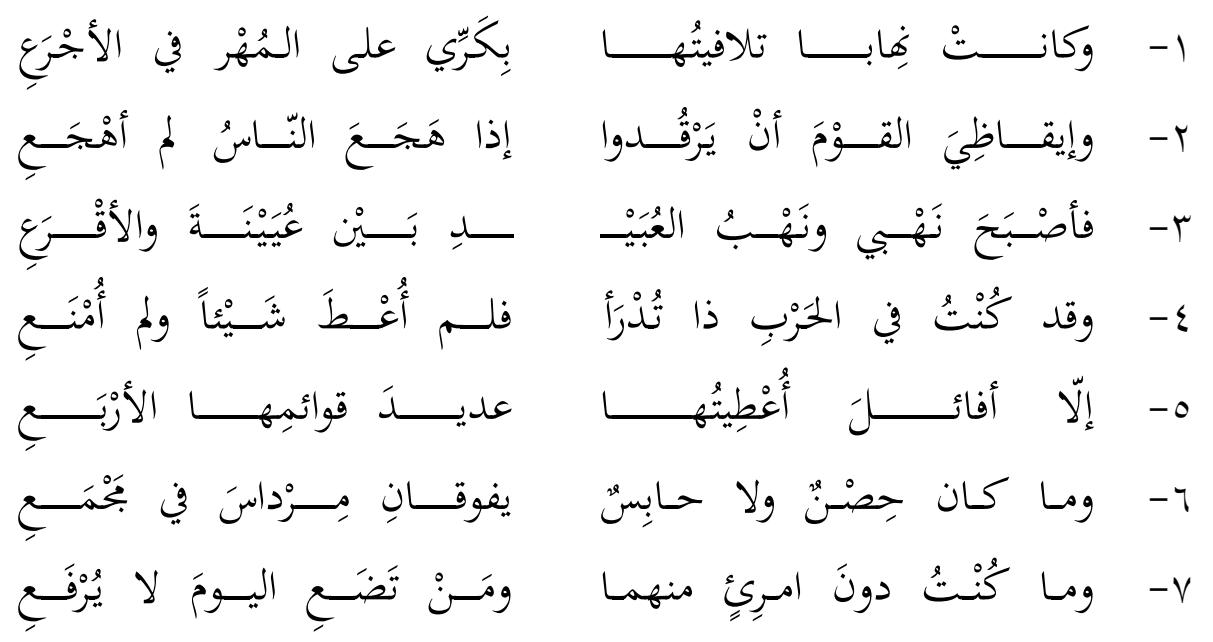

f) 'Abbās's conversion 1, see above p. 155. Aghānī, 192.

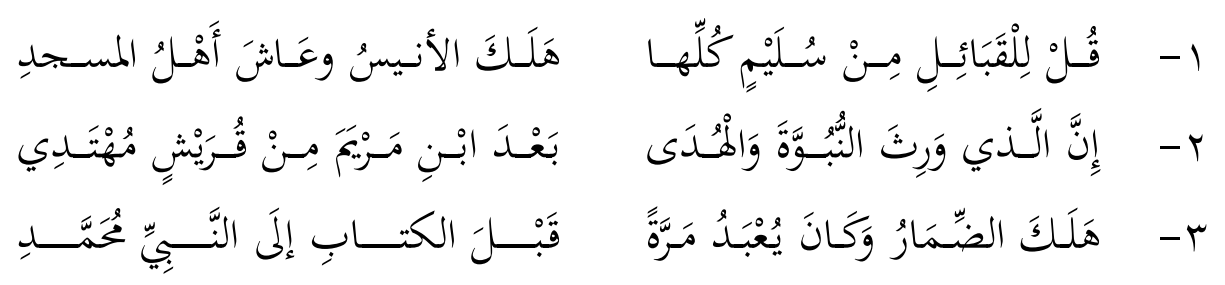

